\section{Human cancer genes}

SIR - In one respect, your News and Views article was startling (Nature 11 November, p.103). You have turned upside down the relative values I attach to the different branches of cancer research. You attribute to me the belief that "the prime objective should be to understand the phenomenon of malignancy . . . (rather than to) concentrate on identifying the causes of cancer"'. This is almost the exact opposite of what I think. In the earlier paper of mine that you cite as evidence of my beliefs (Nature 289, 353-357;

1981), I said that although we know the causes of cancer of the skin and lung, "the preventable causes of the other common cancers are less clear-cut and it may be difficult to identify them until much more is known about mechanism". I go on to say that "eventually the techniques of nucleic acid chemistry should allow us to itemize all the differences in nucleotide sequence and gene expression that distinguish a cancer cell from its normal counterpart, and perhaps at that point the steps involved in carcinogenesis will cease to be in doubt'". That was written in 1980 , and it still seems a reasonable forecast. Indeed, Logan and I finished the News and Views article that immediately follows your piece with the sentence "But we can at least feel that the technology for studying genes and their patterns of expression are now advancing so fast that the molecular biologist will soon be telling the epidemiologist what to look for"

At the risk of being tediously repetitive, let me say it once again. I believe that the only promising strategy, in the foreseeable future, is to learn what are the causes of cancer and then learn how to avoid them. For, in the absence of prevention, all we are left with is treatment - and that seems, at present, to be an intractable problem.

Harvard School of Public Health, Boston, Massachusetts, USA

\section{Cohen-Boyer patent}

SIR - In reading the article about Stanford's response on the "second Cohen-Boyer patent" to the US patent office (Nature 11 November, p.95), one is struck by the editorializing by the author. The matters brought up by the patent examiner were answered very thoroughly by the patent attorney, and interested readers may obtain the response from the patent office to make their own judgements.

We do, however, wish to respond to the issue raised concerning the possible coinventorship of Dr Robert Helling, as the article makes it appear the universities have deliberately sought to exclude Dr Helling from being a co-inventor. The facts are these.

Dr Helling has refused to provide evidence supporting his assertion in the press that he is a co-inventor or otherwise communicate with the patent attorney, Mr Rowland, whose professional responsibility it is to determine that the true inventors are indicated on any patent application he files. Under the rules of the patent office, Mr Rowland now is unable to change his original determination of inventorship unless Dr Helling provides the requested information. Issuance of the patent is not affected by this matter of inventorship. If Dr Helling is an inventor, the universities want his name on the patent. Patent office procedures allow for filing of a reissue of a patent to change named inventors.

Lastly, we are disappointed that documents submitted to the patent office regarding inventorship and available to the author of the article were ignored. These would seem to contradict directly statements to Nature about Dr Helling's role in the invention.

Niels J. Reimers (Director)

Technology Licensing,

Stanford University,

Stanford, California, USA

Stephen Budiansky responds: The documents Mr Reimers refers to are a short summary by Dr Helling of his research activities, filed with the University of California when he left there in 1973, and submitted to the patent office last month by Mr Rowland. I omitted mention of it because it does not bear on the issue of inventorship. In it Helling states that he "participated in developing a procedure for coupling DNA fragments from any source to bacterial plasmids"; this neither supports nor contradicts his claim that he made a significant contribution to the original conception.

Mr Reimer's assertion that Dr Helling refused to provide information to Stanford's attorney is, I understand, a matter of dispute between the parties, and is in any case academic now that the issue of inventorship is under discussion between Dr Helling, Stanford and the patent office.

\section{Green ecology}

SIR - I doubt that I shall be able to dispel the impression gained from the disparaging article "No future for the Greens"' (Nature 28 October, p.766) but I would like to correct some factual inaccuracies.

The Ecology party conference at Bridlington was not its first public meeting; it has held annual conferences since 1974 and additional policy conferences in 1981 and 1982 . All these conferences have been open to outside observers.

Your reporter has also made an error common to ill-informed commentators in suggesting that the Ecology party is solely concerned with environmental issues. As described in its manifesto the Ecology party has policies on all those aspects of life that concern the other British political parties. The difference lies in the application of ecological principles to these concerns in much the same way as the Labour party, for example, would claim to apply socialist principles.

It is correct to suggest that the German Green party (Die Grünen) emphasized environmental issues in the recent elections but this does not imply that such issues are the sole concern of the Ecology party. That the Ecology party does not only consider environmental issues may partially explain the greater impact of Die Grünen, but the difference between British and German electoral systems is probably more important. The third factor hindering recognition of the Ecology party is the inaccurate reporting in the British media of which the abovementioned article is an example.

Southport, UK
Science now and then

SıR - In the course of reviewing Sir Peter Medawar's "Pluto's Republic" (ref.1), Stuart Sutherland commented favourably on the work of K. Popper but less favourably on the work of P. Feyerabend.

Despite Feyerabend's currently anti-

Popperian stance Popper ${ }^{2}$ has recently drawn a distinction between yesterday's "great science" and today's "big science", indicating that the latter should be attacked along Feyerabendian lines. Popper ${ }^{3}$ concluded: "But new ideas should be regarded as precious, and should be carefully nursed; especially if they seem to be a bit wild."

For some of us who were disenchanted 4,5 with the "big science" of the previous decade, Feyerabend was the philosopher of science. However, there is evidence that " big chemistry" (at least) is becoming more rational and more tolerant of low status authors 6,7 who publish critical reviews. Thus, Popper's position, strengthened by the recent publication ${ }^{8}$ of "Postscript", is becoming increasingly more attractive.

It is currently considered ${ }^{9-11}$ that the "chemical revolution"' initiated by Lavoisier originated from a Feyerabendian assault rather than from a Popperian "problem situation" or a Kuhnian "crisis". Similar judgements ${ }^{12,13}$ are also accorded on Liebig's "biochemical revolution". In both cases the innovators relied on a mixture of empirical evidence and unsupported speculation to justify their theories.

Fruton 14 concludes: "Although most of Liebig's physiological speculations were rejected by several contemporary critics and soon became untenable, there can be little doubt that they stimulated the study of physiological processes from a chemical point of view. The public position that he had won through his achievements in organic chemistry, both as an investigator and as a teacher, assured a respectful hearing for his bold hypothesis. In seeking to prove or disprove Liebig's ideas, his defenders and critics were spurred to examine more closely substances (such as the proteins) present in living organisms...."

F.M.AKEROYD

Bradford \& Ilkley Community College, Bradford, UK

Sutherland, S. Nature 300, 118-119 (1982)

Popper, K.R. in Scientific Revolutions (ed. Hacking, I.) 89 96, 106 (Oxford University Press, 198!).

3. Popper, K.R. in Scientific Revolutions (ed. Hacking, I.) 97 (Oxford University Press, 1981).

4. Ninio, J. Trends biochem. Sci. July, vii (1981).

5. Akeroyd, F.M. Trends biochem. Sci. 7, 241 (1982)

Ginsburg, D. Acc chem. Res, 15, $199(1982)$

Akeroyd I. M. Chem. Br. 18, 481-482(1982).

8. Popper, K.R. Postscript to the Logic of Scientific Discovery (cd. Bradlcy, W.W. III) (Hutchinson, London,
coper,

9. Ihde, A.J. in Joseph Priestley (cds Kieft, L. \& Willeford. B. J.) 77.78 (Bucknell University Press, 1980).

0. Teich, M. Ambix 29. 17-21 (1982)

11. Fisher, N. Br. J. Hist. Sci. 14, 214-216(1981).

12. Holmes, F,1.. Introduction to the fascimile edition of I, icbig's Animal Chemistry (Johnson Reprint Corporation. New York, 1964).

13. Fruton, J.S. Molecules and Life, 267-269 (Wilcy, New York, 1972)

14. Fruton, 3.S. Molecules and Life, 272 (Wilcy. New York, 1972). 